UDC 579.61

DOI: $10.15587 / 2519-8025.2020 .202216$

\title{
METHODICAL APPROACHES OF ESTIMATION OF PROBIOTICS`QUALITY AND RATIONAL PRINCIPLES OF THEIR USAGE IN CLINICAL PRACTICE
}

\author{
L. Lazarenko, R. Bubnov, L. Babenko, O. Melnykova, M. Spivak
}

\begin{abstract}
Останнім часом пробіотики стали широко використовувати в якості допоміжної терапії при багатьох захворюваннях, таких як кишкові і урогенітальні інфекиіі, захворювання шлунково-кишкового тракту $i$ дихальних шляхів, а також ураження суглобів і сполучної тканини, деякі види раку, алергії, дерматологічні та стоматологічні захворювання. Тим не мени, до циих пір немає зведених рекомендацій з відбору та оцінки ефективності пробіотичних штамів для різних клінічних випадків. Тому в даній роботі нами була зібрана і проаналізована інформаџія про методи оцінки якості пробіотиків і розробку раціональних принцииів застосування пробіотиків в клінічній практиці при лікуванні пацієнтів з найбільш поширеними захворюваннями $i$ їх профілактиці. Описано основні принципи впровадження покрокової оцінки якості пробіотичної культури в харчових продуктах відповідно до нормативних актів Всесвітньої організачії охорони здоров'я, Свропейського Союзу, України та інших країн. Представлені вимоги для очінки безпеки пробіотичних культур, які включають тестування їх активності in vitro ma in vivo на різних експериментальних моделях, а також вивчення їх терапевтичної ефективності в клінічній практиці при лікуванні пацієнтів і протягом тривалого періоду після пробіотичної терапії. Також в статті наведені дані щзодо можливих побічних ефектів, ризиків або низької ефективності застосування пробіотиків, які залежать від індивідуальних характеристик кожного пацієнта, кількісного $і$ якісного складу кишкової мікробіоти, стадії і тяжкості клінічного перебігу кожного конкретного захворювання. Виходячи з изого, дуже важливо враховувати всі особливості організму пацієнтів $і$ збирати всі раніше накопичені знання про використання пробіотиків
\end{abstract}

Ключові слова: пробіотики, захворювання, оцінка, безпека, клінічна практика, терапія

Copyright (C) 2020, L. Lazarenko, R. Bubnov, L. Babenko, O. Melnykova, M. Spivak. This is an open access article under the CC BY license (http://creativecommons.org/licenses/by/4.0).

\section{Introduction}

The development of probiotics for the prevention and treatment of the most common diseases, including infectious-inflammatory processes, is an important area of modern biotechnology, microbiology, immunology and medicine $[1,2]$. Probiotics have a wide range of biological activity: affect metabolism; improve the barrier function of the gastrointestinal tract; normalize the qualitative and quantitative composition of microbiota of different human biotopes and the development of the inflammatory response of the organism; decrease intestinal $\mathrm{pH}$; reduce colonization and invasion by pathogens; inhibit the growth of opportunistic microorganisms and so on $[3,4]$. Probiotics (immunobiotics), that interact with different recognition receptors (e.g. Toll-like), expressed in non-immune and immune cells, have immunomodulatory efficacy, aimed at balancing the production of a number of pro- and anti-inflammatory cytokines [5].

So, the aim of the work was to collect and analyze relevant information about estimation of probiotics ' quality and development of rational principles of probiotic therapy usage in clinical practice during the treatment of patients with the most common diseases and for their prevention.

\section{Proven benefits of using probiotics}

The results of many clinical and experimental studies have substantiated the feasibility of using safe drugs of natural origin - probiotics, created on the basis of commensal microbiota of the mucous membranes of humans (especially different strains of lactobacilli (LAB)), as well as for the prevention of infectiousinflammatory and other diseases and increasing of clinical efficacy of the individual complex treatment of patients. Nowadays probiotics are widely used in clinical practice in the treatment of patients with acute intestinal infections; diseases of the gastrointestinal tract (gastric ulcer and 12 duodenal ulcer, pancreatitis, cholecystitis, liver and biliary tract diseases, enteritis, viral hepatitis, gastritis, colitis); respiratory tract (pneumonia, bronchitis, etc.), urogenital system, also joints and connective tissue lesions, some cancers, allergies, dermatological and dental diseases, urolithiasis, etc. [1, 6, 7]. Probiotic therapy is performed together with etiotropic therapy or alone and is used in patients of all age groups, including newborns. The scope of probiotics is constantly expanding. Thus, the results of the meta-analysis showed the effectiveness of probiotic therapy in patients with type 2 diabetes [8,9], irritable bowel syndrome [10], Helicobacter pylori-associated diseases [11], depressive states [12], atopic dermatitis (in children) [13]. The results of the meta-analysis showed that cellular immune response in healthy elderly people was activated as a result of probiotic therapy [14]. Probiotics are used to prevent postoperative complications (pneumonia and sepsis), as well as reduce the duration of antibiotic treatment and staying in hospital [15]. Probiotic therapy has been effective in sepsis preventing and colonization of the gastrointestinal 
tract by microscopic fungi of the Candida genus in preterm infants. The usage of probiotics reduced the severity of necrotic enterocolitis and mortality in premature infants and facilitated the course of antibioticinduced diarrhea in critically ill children $[16,17]$. According to the meta-analysis, the effectiveness of probiotic therapy has also been proven in various experimental models in animals: experimental acute pancreatitis [18], necrotic enterocolitis [19], and obesity [20]. Probiotic strains of lactobacilli and bifidobacteria had antibacterial, anti-inflammatory and immunomodulatory effects in the experimental generalized staphylococcal infection [21].

At the same time, some clinical and experimental studies have shown a limited efficacy or even ineffectiveness of probiotic therapy. Therefore, the use of probiotics has been ineffective in gastrointestinal tract dysbiosis [22], excessive bacterial growth in the small intestine [23], functional constipation in children [24], schizophrenia [25], during the treatment of patients with pneumonia in intensive care units [26]. Probiotics had no therapeutic effect in the experimental model of cryptococcosis [27] and intestinal dysbiosis [22].

The low efficiency or inefficiency of probiotics, first of all, is related to the fact that only a small number of living probiotic microorganisms are engrafted in gut; they do not integrate into biofilms and do not perform their physiological functions. It is believed, that the optimal positive effect of probiotics depends on individual characteristics of quantitative and qualitative composition of the gut microbiota and clinical manifestations of each specific disease [28]. Therefore, to increase the effectiveness of probiotic therapy, it is advisable to create probiotics, specific to each individual disease [29], and also to implement in clinical practice rational schemes of their personalized usage [30], taking into account the optimal dosage regimens and the duration of probiotic therapy, depending on age, nature of the course and severity of the pathological process of the patient, level of dysbiotic and immune disorders; as well as a rational way of their introduction (oral, rectal, vaginal) [1]. It's important to mean, that probiotics should be administered at least two hours after antibiotics' administration in cases, where probiotic therapy is carried out with etiotropic therapy [2].

\section{Key principles of probiotics assessment}

Nowadays the key principles of probiotic assessment in food are identified and a step-by-step estimation of probiotics quality is recommended, using a proposed scheme that provides testing of safety and efficacy of probiotic cultures in vitro and in vivo. The main requirements for probiotics are safety; resistance to gastric juice, bile, phenol, food enzymes and so on; antagonistic activity against pathogenic and opportunistic microorganisms; high biosynthetic activity; immunomodulatory properties; natural resistance to antibiotics, especially those, widely used in clinical practice; normalization of the qualitative and quantitative composition of microbiota of different biotopes; rapid reactivation of the biomass in biotopes, etc. $[1,2]$. Probiotics and functional food with probiotic activity are generally considered as safe and well tolerated. At the same time, the clinical effective- ness of probiotics was found to depend on factors, such as their species and strain composition; the concentration of cells of certain types of microorganisms; technologies of their production; as well as the nature of microecological disturbances in the macroorganism qualitative and quantitative composition of microbiota of different biotopes; immune system state and features of clinical course of pathological processes, etc. [1, 2]. An important requirement for probiotics is also their multifactorial effect [3].

The main criteria for the selection of probiotics are their quality (qualitative and quantitative composition of probiotic cultures, confirmed by microbiological analysis and genotyping), as well as efficiency and safety, confirmed by the results of their use in clinical practice. According to regulations from the World Health Organization (WHO) and the US Food and Drug Administration (FDA), probiotics, above all, representatives of the genera Lactococcus and Lactobacillus, have the GRAS (Generally Regarded As Safe) status, that is, they are generally safe. Lactobacilli have a long history of being used as a probiotic with no identified human risk; they do not show pathogenic or virulent properties, which are considered the best evidence of their safety. In this regard, unrestricted use of probiotic cultures of lactobacilli in food and pharmaceutical industries is permitted [31, 32].

The results of controlled clinical trials have shown the safety of most probiotics, used for the treatment of adult patients, children and newborns, and also diseases prevention [7, 33, 34]. However, today there are several theoretical views regarding the safety of probiotic therapy:

1) the development of local or systemic infections, including bacteremia, fungemia, meningitis, endocarditis, etc. $[7,10]$;

2) the occurrence of metabolic and toxic disorders (e.g. invasion of epithelial cells, degradation of the intestinal layer of mucin, production of toxins, etc.);

3) transfer of plasmids, containing antibiotic resistance genes and virulence factors in the gastrointestinal microbiota, and as a result of the formation of new clones of bacterial strains;

4) excessive stimulation of the immune system in susceptible individuals [32, 35], which threatens human health $[36,37]$.

The most common complications after probiotic therapy occurred in critically ill patients in the ICU; patients, who underwent surgery; in critically ill children [10]. Probiotics should be used with caution in patients with severe immunodeficiency or in patients with central venous catheters to avoid side effects such as systemic infections [2]. In some clinical cases, probiotics have caused bacteremia, fungemia, and sepsis in immunocompromised children [16]. It is important to note, that cases of local and systemic infectious processes, induced by lactobacilli and bifidobacteria are extremely rare in adult patients. For example, infectious endocarditis and bacteremia after probiotic therapy were found in only $0.05-0.4 \%$ of cases [38, 39]. Following the consumption of probiotic strains of lactobacilli and bifidobacteria in food, the risk of bacteremia is also low [40]. Lactobacillemia due to the consumption of fermented dairy products is extremely rare only in sensitive individuals [41]. 
Also these side effects of probiotic therapy depend on the taxonomic nature and biological properties of the strains of probiotic cultures [1]. The safety of probiotic cultures that are part of probiotics is controlled in the United States in accordance with FDA requirements, and in the European Union - the Food Safety Authority (EFSA), International Organization for Standardization (ISO), Food and Agriculture Organization (FAO), and WHO. In Ukraine, the issue of quality and biosafety of probiotics (food supplements) is regulated by such normative acts as the State Pharmacopoeia of Ukraine and the Law of Ukraine "About Basic Principles and Requirements for Food Safety and Quality", which provides usage of regulatory requirements of the USA and the European Union. The main requirements for probiotics are safety; resistance to gastric juice, bile, phenol, food enzymes, etc.; antagonistic activity against pathogenic and opportunistic microorganisms; high biosynthetic activity; immunomodulatory properties; natural resistance to antibiotics, especially those, widely used in clinical practice; normalization of the qualitative and quantitative composition of microbiota of different biotopes; rapid reactivation of the biomass in biotopes and so on $[1,2]$.

The Guidelines for the Evaluation of Probiotics in Food, adopted jointly by the FAO and WHO Working Groups in 2002, set out key principles for evaluation of probiotics in food [42].

A step-by-step assessment of the quality of probiotics is recommended by the standard scheme:

- identify the strain, using phenotypic and genotypic research methods (determine genus, species, strain) and deposit it in an international collection of microorganisms;

- investigate the functional properties in vitro and in vivo, using animal models;

- estimate safety in vitro and in vivo, using animal models as well as in clinical studies (Stage 1);

- conduct double-blind, randomized placebocontrolled clinical trials (Stage 2); other independent double-blind, randomized, placebo-controlled clinical trials are recommended to confirm positive results;

- compare the effectiveness of a probiotic to the standard treatment (Stage 3);

- conduct prolonged observations after conducting probiotic therapy (Stage 4); determine their side effects.

Foods with probiotic properties (dietary supplements) are not usually tested in Stage 3, which is for comparison to the standard therapy. Important in evaluating of effectiveness of probiotic therapy are: improving the quality of life and health of people; reducing the risk of disease or reducing the rate of relapse; rapid recovery from illness and the like. Each of these features should correlate with a probiotic under study [42].

\section{Evaluation of safety of probiotics}

The main requirements for the safety of probiotics are: 1) their clear genus, species and strain identification;

2) identification of non-pathogenicity for humans and animals;

3) detection of plasmids, containing antibiotic resistance genes and virulence factors;
4) evaluation of metabolic activity (e.g. production of D-lactate, deconjugation of bile salts, etc.);

5) study of the ability of a, strain belonging to a species known, to be a mammalian toxin producer or hemolytic potential for the production of toxins (one of the possible schemes for testing toxins was recommended by the EU Scientific Committee on Animal Nutrition in 2000) and its hemolytic activity [37];

6) determination of immunotoxicity $[42,43]$;

7) detection of adverse side effects during probiotic testing in clinical trials and in long periods after probiotic therapy (after entering the market) [44, 45]. Much attention is paid to the genetic stability of probiotic cultures, as well as the risk of their translocation into the peripheral blood and internal organs and tissues, for example, due to the increased permeability of gastrointestinal mucosa during inflammatory diseases [7].

Probiotic cultures that are part of probiotics must be identified at the generic and species level and have a strain passport. Traditionally, lactic acid bacteria are classified on the basis of morphological and cultural characteristics and physiological and biochemical properties, such as morphology, glucose fermentation method, growth at different temperatures, configuration of synthesized lactic acid, spectrum of fermented carbohydrates and so on. However, some species are difficult to discern by these signs. Particularly there are L. acidophilus, $L$. casei and $L$. paracasei, as well as some bifidobacteria that are part of probiotics and lactic acid products, such as yoghurts. Therefore, polymerase chain reaction (PCR), analysis of the 16s RNA gene are used for the identification of species or differentiation of probiotic strains, as well as methods of molecular typing, such as gel electrophoresis in a pulsed field, repeated PCR and the determination of restriction fragment length polymorphism and so on. Species or even name of genus may indicate strain's safety and technical suitability for usage in probiotic products [46]. The identification of lactic acid bacteria must combine the determination of morphological and cultural traits and physiological and biochemical properties and genotypic signs [42], same as to eliminate falsification and to periodically control identity of the original strain and the production culture in the process of cultivation, and also to exclude its heterogeneity. Genetic characteristics of the strain should include data regarding the absence of extrachromosomal hereditary factors - plasmids, transposons, bacteriophages in a genome.

The assessment of the safety of probiotic cultures is carried out in vitro and in vivo. According to the Guidelines for the Evaluation of Probiotics in Foods, adopted jointly by the FAO and WHO Working Groups in 2002, in vitro tests are used to determine the resistance of probiotic cultures to acids and bile; antimicrobial activity against potentially pathogenic bacteria; bile acid salt hydrolase activity; resistance to spermicides (for probiotics that are administered vaginally), their adhesion to the mucous membranes or epithelial cells of human and cell lines, resistance to antibiotics and the like [42]. Lactic acid bacteria have proven to be resistant to many antibiotics, but in many cases such resistance has not been transmissible. At the same time, they were sensitive to many of the main antibiotics, which used in clinical 
practice (e.g. vancomycin, metronidazole, fidaxomicin, etc.) $[31,40,47]$. It is important to note, that the "classical" safety assessment approaches that apply to pathogens are not justified for determination of safety of commensal lactobacilli and bifidobacteria. In particular, during determination of the risk assessment for pathogens, their pathogenicity is usually a consequence of several properties, including colonization and concerted virulence factors. Often factors such as adhesion are considered as virulence factors in the study of pathogens. However, adhesion to a mucous membrane and other colonization factors are important features for most commensals [40].

For lactobacilli and bifidobacteria safe probiotic cultures screening it is proposed to study the production of biogenic amines, nitrogen reductase; to determine $\beta$-glucuronidase activity, thrombin induction, thrombin dissolution under the influence of various hydrolases, thrombocyte aggregation, adhesion to fibrinogen or fibronectin, and also mucin degradation and hemolysis [40].

Animal models are widely used during the study of probiotic cultures safety in vivo, different lines of immunodeficient animals (including gnotobionts) are most often used [44]. The pathogenicity of probiotics, their acute and chronic toxicity, as well as dermatonecroticity, immunotoxicity, translocation to the peripheral blood and internal organs are determined in experimental models using at least 2 species (nonlinear or linear) or 2 lines of one species. Clinical signs of respiratory intoxication (difficulty in nasal breathing, change in frequency, depth of breath, change in skin color), motor activity (decrease or increase in spontaneous motor activity, drowsiness) the vascular system, the gastrointestinal tract and so on are detected during evaluation of acute and chronic toxicity of probiotic cultures. After probiotic therapy it is necessary to investigate changes in biochemical and hematological parameters and detect histological changes in the internal organs of animals [48]. The safety of probiotics is confirmed by the absence of side effects during the probiotic therapy in clinical practice and in the long periods after it $[42,49]$.

\section{Conclusion}

The usage of the above methodical approaches to estimate the quality of probiotic cultures in the development of probiotics (immunobiotics) and the introduction of rational schemes of probiotic therapy into clinical practice will allow to increase the effectiveness of prevention of the most common diseases and of the complex personalized treatment of patients, as well as to avoid side effects.

\section{Conflicts of interest} interest.

The authors declare that they have no conflicts of

\section{References}

1. Shirobokov, V. P., Shirobokov, V. P., Iankovskii, D. S., Dyment, G. S. (2010). Mikrobnaia ekologiia cheloveka s tsvetnym atlasom. Kyiv: Chervona Ruta-Turs, 340.

2. Williams, N. T. (2010). Probiotics. American Journal of Health-System Pharmacy, 67 (6), 449-458. doi: http://doi.org/10.2146/ajhp090168

3. Halloran, K., Underwood, M. A. (2019). Probiotic mechanisms of action. Early Human Development, 135, 58-65. doi: http://doi.org/10.1016/j.earlhumdev.2019.05.010

4. Nichols, R. G., Peters, J. M., Patterson, A. D. (2019). Interplay Between the Host, the Human Microbiome, and Drug Metabolism. Human Genomics, 13 (1). doi: http://doi.org/10.1186/s40246-019-0211-9

5. Azad, M. A. K., Sarker, M., Wan, D. (2018). Immunomodulatory Effects of Probiotics on Cytokine Profiles. BioMed Research International, 2018, 1-10. doi: http://doi.org/10.1155/2018/8063647

6. Falagas, M. E., Betsi, G. I., Tokas, T., Athanasiou, S. (2006). Probiotics for prevention of recurrent urinary tract infections in women: a review of the evidence from microbiological and clinical studies. Drugs, 66 (9), 1253-1261. doi: http://doi.org/10.2165/00003495-200666090-00007

7. Di Cerbo, A., Palmieri, B., Aponte, M., Morales-Medina, J. C., Iannitti, T. (2015). Mechanisms and therapeutic effectiveness of lactobacilli. Journal of Clinical Pathology, 69 (3), 187-203. doi: http://doi.org/10.1136/jclinpath-2015-202976

8. Kasińska, M. A., Drzewoski, J. (2015). Effectiveness of probiotics in type 2 diabetes: a meta-analysis. Polish Archives of Internal Medicine, 125 (11), 803-813. doi: http://doi.org/10.20452/pamw.3156

9. Hendijani, F., Akbari, V. (2018). Probiotic supplementation for management of cardiovascular risk factors in adults with type II diabetes: A systematic review and meta-analysis. Clinical Nutrition, 37 (2), 532-541. doi: http://doi.org/10.1016/j.clnu.2017.02.015

10. Didari, T., Mozaffari, S., Nikfar, S., Abdollahi, M. (2015). Effectiveness of probiotics in irritable bowel syndrome: Updated systematic review with meta-analysis. World Journal of Gastroenterology, 21 (10), 3072-3084. doi: http://doi.org/10.3748/wjg.v21.i10.3072

11. Wang, F., Feng, J., Chen, P., Liu, X., Ma, M., Zhou, R. et. al. (2017). Probiotics in Helicobacter pylori eradication therapy: Systematic review and network meta-analysis. Clinics and Research in Hepatology and Gastroenterology, 41 (4), 466-475. doi: http://doi.org/10.1016/j.clinre.2017.04.004

12. Huang, R., Wang, K., Hu, J. (2016). Effect of Probiotics on Depression: A Systematic Review and Meta-Analysis of Randomized Controlled Trials. Nutrients, 8 (8), 483. doi: http://doi.org/10.3390/nu8080483

13. Chang, Y.-S., Trivedi, M. K., Jha, A., Lin, Y.-F., Dimaano, L., García-Romero, M. T. (2016). Synbiotics for Prevention and Treatment of Atopic Dermatitis: A Meta-analysis of Randomized Clinical Trials. JAMA Pediatrics, 170 (3), 236-242. doi: http://doi.org/10.1001/jamapediatrics.2015.3943

14. Miller, L. E., Lehtoranta, L., Lehtinen, M. J. (2019). Short-term probiotic supplementation enhances cellular immune function in healthy elderly: systematic review and meta-analysis of controlled studies. Nutrition Research, 64, 1-8. doi: http://doi.org/10.1016/j.nutres.2018.12.011

15. Kasatpibal, N., Whitney, J. D., Saokaew, S., Kengkla, K., Heitkemper, M. M., Apisarnthanarak, A. (2017). Effectiveness of Probiotic, Prebiotic, and Synbiotic Therapies in Reducing Postoperative Complications: A Systematic Review and Network Metaanalysis. Clinical Infectious Diseases, 64 (suppl_2), S153-S160. doi: http://doi.org/10.1093/cid/cix114 
16. Singhi, S. C., Kumar, S. (2016). Probiotics in critically ill children. F1000Research, 5, 407. doi: http://doi.org/10.12688/f1000research.7630.1

17. Mantegazza, C., Molinari, P., D’Auria, E., Sonnino, M., Morelli, L., Zuccotti, G. V. (2018). Probiotics and antibioticassociated diarrhea in children: A review and new evidence on Lactobacillus rhamnosus GG during and after antibiotic treatment. Pharmacological Research, 128, 63-72. doi: http://doi.org/10.1016/j.phrs.2017.08.001

18. Hooijmans, C. R., de Vries, R. B. M., Rovers, M. M., Gooszen, H. G., Ritskes-Hoitinga, M. (2012). The Effects of Probiotic Supplementation on Experimental Acute Pancreatitis: A Systematic Review and Meta-Analysis. PLoS ONE, 7 (11), e48811. doi: http://doi.org/10.1371/journal.pone.0048811

19. Athalye-Jape, G., Rao, S., Patole, S. (2017). Effects of probiotics on experimental necrotizing enterocolitis: a systematic review and meta-analysis. Pediatric Research, 83 (1), 16-22. doi: http://doi.org/10.1038/pr.2017.218

20. Million, M., Angelakis, E., Paul, M., Armougom, F., Leibovici, L., Raoult, D. (2012). Comparative meta-analysis of the effect of Lactobacillus species on weight gain in humans and animals. Microbial Pathogenesis, 53 (2), 100-108. doi: http://doi.org/10.1016/j.micpath.2012.05.007

21. Mokrozub, V. V., Lazarenko, L. M., Babenko, L. P. (2013). Antistaphylococcal action of lacto- and bifidobacteria and interleukine-2. Mikrobiological Journal, 75 (6), 17-21.

22. Suez, J., Zmora, N., Zilberman-Schapira, G., Mor, U., Dori-Bachash, M., Bashiardes, S. et. al. (2018). Post-Antibiotic Gut Mucosal Microbiome Reconstitution Is Impaired by Probiotics and Improved by Autologous FMT. Cell, 174 (6), $1406-1423$. doi: http://doi.org/10.1016/j.cell.2018.08.047

23. Zhong, C., Qu, C., Wang, B., Liang, S., Zeng, B. (2017). Probiotics for Preventing and Treating Small Intestinal Bacterial Overgrowth: A Meta-Analysis and Systematic Review of Current Evidence. Journal of Clinical Gastroenterology, 51 (4), 300-311. doi: http://doi.org/10.1097/mcg.0000000000000814

24. Wojtyniak, K., Szajewska, H. (2017). Systematic review: probiotics for functional constipation in children. European Journal of Pediatrics, 176 (9), 1155-1162. doi: http://doi.org/10.1007/s00431-017-2972-2

25. Ng, Q. X., Soh, A. Y. S., Venkatanarayanan, N., Ho, C. Y. X., Lim, D. Y., Yeo, W.-S. (2019). A Systematic Review of the Effect of Probiotic Supplementation on Schizophrenia Symptoms. Neuropsychobiology, 78 (1), 1-6. doi: http://doi.org/10.1159/000498862

26. Bo, L., Li, J., Tao, T., Bai, Y., Ye, X., Hotchkiss, R. S. et. al. (2014). Probiotics for preventing ventilator-associated pneumonia. Cochrane database of systematic reviews, 10 (10), 1465-1858. doi: http://doi.org/10.1002/14651858.cd009066.pub2

27. Oliveira, L. V. N. de, Bastos, R. W., Ribeiro, N. de Q., Costa, M. C., Acurcio, L. B., Rocha, K. M. et. al. (2017). In vivo probiotic and antimicrobial photodynamic therapy as alternative therapies against cryptococcosis are ineffective. Veterinary Microbiology, 211, 169-173. doi: http://doi.org/10.1016/j.vetmic.2017.08.015

28. Shentsova, M. A., Surmasheva, O. V. (2014). Probiotic preparations, their quality and safety: current state (part II). Dovkillia i zdorovia, 1, 64-69.

29. Timmerman, H. M., Niers, L. E. M., Ridwan, B. U., Koning, C. J. M., Mulder, L., Akkermans, L. M. A. et. al. (2007) Design of a multispecies probiotic mixture to prevent infectious complications in critically ill patients. Clinical Nutrition, 26 (4), 450-459. doi: http://doi.org/10.1016/j.clnu.2007.04.008

30. Zmora, N., Zilberman-Schapira, G., Suez, J., Mor, U., Dori-Bachash, M., Bashiardes, S. et. al. (2018). Personalized Gut Mucosal Colonization Resistance to Empiric Probiotics Is Associated with Unique Host and Microbiome Features. Cell, 174 (6), 1388-1405. doi: http://doi.org/10.1016/j.cell.2018.08.041

31. Salminen, S., von Wright, A., Morelli, L., Marteau, P., Brassart, D., de Vos, W. M. (1998). Demonstration of safety of probiotics - a review. International Journal of Food Microbiology, 44 (1-2), 93-106. doi: http://doi.org/10.1016/s01681605(98)00128-7

32. Marteau, P., Seksik, P., Jian, R. (2002). Probiotics and health: new facts and ideas. Current Opinion in Biotechnology, 13 (5), 486-489. doi: http://doi.org/10.1016/s0958-1669(02)00368-3

33. Snydman, D. R. (2008). The Safety of Probiotics. Clinical Infectious Diseases, 46 (s2), S104-S111. doi: http://doi.org/10.1086/523331

34. Mayes, T., Gottschlich, M. M., James, L. E., Allgeier, C., Weitz, J., Kagan, R. J. (2015). Clinical Safety and Efficacy of Probiotic Administration Following Burn Injury. Journal of Burn Care \& Research, 36 (1), 92-99. doi: http://doi.org/10.1097/bcr.0000000000000139

35. Marteau, P. R. (2002). Probiotics in clinical conditions. Clinical Reviews in Allergy \& Immunology, 22 (3), $255-273$. doi: http://doi.org/10.1007/s12016-002-0011-0

36. Shanahan, F. (2012). A Commentary on the Safety of Probiotics. Gastroenterology Clinics of North America, 41 (4), 869-876. doi: http://doi.org/10.1016/j.gtc.2012.08.006

37. Doron, S., Snydman, D. R. (2015). Risk and Safety of Probiotics. Clinical Infectious Diseases, 60 (suppl_2), S129-S134. doi: http://doi.org/10.1093/cid/civ085

38. Gasser, F. (1994). Safety of lactic-acid bacteria and their occurrence in human clinical infections. Bulletin de L'Institut Pasteur, 92, 45-67.

39. Saxelin, M., Chuang, N.-H., Chassy, B., Rautelin, H., Makela, P. H., Salminen, S., Gorbach, S. L. (1996). Lactobacilli and Bacteremia in Southern Finland, 1989-1992. Clinical Infectious Diseases, 22 (3), 564-566. doi: http://doi.org/10.1093/clinids/22.3.564

40. Borriello, S. P., Hammes, W. P., Holzapfel, W., Marteau, P., Schrezenmeir, J., Vaara, M., Valtonen, V. (2003). Safety of Probiotics That Contain Lactobacilli or Bifidobacteria. Clinical Infectious Diseases, 36 (6), 775-780. doi: http://doi.org/10.1086/368080

41. Bernardeau, M., Vernoux, J. P., Henri-Dubernet, S., Guéguena, M. (2008). Safety assessment of dairy microorganisms: the Lactobacillus genus. International Journal of Food Microbiology, 126 (3), 278-285. doi: http://doi.org/10.1016/j.ijfoodmicro.2007.08.015

42. Guidelines for the Evaluation of Probiotics (2002). Food Report of a Joint FAO/WHO Working Group on Drafting Guidelines for the Evaluation of Probiotics in Food London Ontario. Canada. Available at: https://www.who.int/foodsafety/ fs management/en/probiotic guidelines.pdf 
43. Saarela, M., Mogensen, G., Fondén, R., Mättö, J., Mattila-Sandholm, T. (2000). Probiotic bacteria: safety, functional and technological properties. Journal of Biotechnology, 84 (3), 197-215. doi: http://doi.org/10.1016/s0168-1656(00)00375-8

44. Ishibashi, N., Yamazaki, S. (2001). Probiotics and safety. The American Journal of Clinical Nutrition, 73 (2), 465s-470s. doi: http://doi.org/10.1093/ajen/73.2.465s

45. Doron, S., Hibberd, P. L., Goldin, B., Thorpe, C., McDermott, L., Snydman, D. R. (2015). Effect of Lactobacillus rhamnosus GG Administration on Vancomycin-Resistant Enterococcus Colonization in Adults with Comorbidities. Antimicrobial Agents and Chemotherapy, 59 (8), 4593-4599. doi: http://doi.org/10.1128/aac.00300-15

46. Holzapfel, W. H., Haberer, P., Geisen, R., Björkroth, J., Schillinger, U. (2001). Taxonomy and important features of probiotic microorganisms in food and nutrition. The American Journal of Clinical Nutrition, 73 (2), 365s-373s. doi: http://doi.org/10.1093/ajcn/73.2.365s

47. Klein, G. (2011). Antibiotic Resistance and Molecular Characterization of Probiotic and ClinicalLactobacillusStrains in Relation to Safety Aspects of Probiotics. Foodborne Pathogens and Disease, 8 (2), $267-281$. doi: http://doi.org/10.1089/fpd.2010.0672

48. Stefanov, A. V. (Ed.) (2002). Doklinicheskie issledovaniia lekarstvennykh sredstv. Metodicheskie rekomendatsii. Kyiv: Avitsena, 568.

49. Liaskovskii, T. M., Podgorskii, V. S. (2005). Otsenka probiotikov soglasno rekomendatsii mezhdunarodnykh organizatsii (FAO/WHO). Mikrobiologicheskii zhurnal, 67 (6), 104-112.

Received date 29.01.2020

Accepted date 04.02.2020

Published date 28.02.2020

Liudmyla Lazarenko, Doctor of Biological Sciences, Senior Researcher, Leading Researcher, Department of Interferon and Immunomodulators, D. K. Zabolotny Institute of Microbiology and Virology of National Academy of Sciences of Ukraine, Akademika Zabolotnoho str., 154, Kyiv, Ukraine, 03143

Email: LazarenkoLM@gmail.com

Rostyslav Bubnov, PhD, Senior Researcher, Department of Interferon and Immunomodulators, D. K. Zabolotny Institute of Microbiology and Virology of National Academy of Sciences of Ukraine, Akademika Zabolotnoho str., 154, Kyiv, Ukraine, 03143

Email: dr.rbubnov@gmail.com

Lidiia Babenko, PhD, Researcher, Department of Interferon and Immunomodulators, D. K. Zabolotny Institute of Microbiology and Virology of National Academy of Sciences of Ukraine, Akademika Zabolotnoho str., 154, Kyiv, Ukraine, 03143

E-mail: babenkolidiia@gmail.com

Oleksandra Melnykova, Department of Microbiology and Immunology, Educational Scientific Center "Institute of Biology and Medicine" Taras Shevchenko National University of Kyiv, Volodymyrska str., 64/13, Kyiv, Ukraine, 01601

E-mail: alex190697@ukr.net

Mykola Spivak, Doctor of Biological Sciences, Professor, Corresponding Member of National Academy of Sciences of Ukraine, Head of Department, Department of Interferon and Immunomodulators, D. K. Zabolotny Institute of Microbiology and Virology of National Academy of Sciences of Ukraine, Akademika Zabolotnoho str., 154, Kyiv, Ukraine, 03143

E-mail: n.spivak@ukr.net 